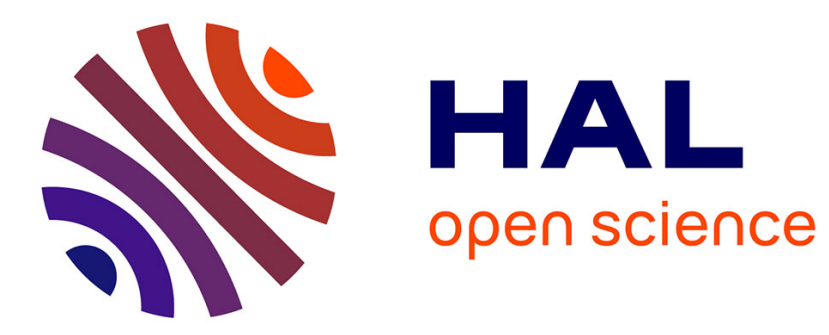

\title{
Phenoxyethanol, reproduction and development: additional studies are needed
}

Ronan Garlantézec, C. Warembourg, R. Beranger, Cécile Chevrier

\section{To cite this version:}

Ronan Garlantézec, C. Warembourg, R. Beranger, Cécile Chevrier. Phenoxyethanol, reproduction and development: additional studies are needed. Journal of the European Academy of Dermatology and Venereology, 2020, 34 (8), 10.1111/jdv.16344 . hal-02796994

\section{HAL Id: hal-02796994}

\section{https://hal-univ-rennes1.archives-ouvertes.fr/hal-02796994}

Submitted on 12 Jun 2020

HAL is a multi-disciplinary open access archive for the deposit and dissemination of scientific research documents, whether they are published or not. The documents may come from teaching and research institutions in France or abroad, or from public or private research centers.
L'archive ouverte pluridisciplinaire HAL, est destinée au dépôt et à la diffusion de documents scientifiques de niveau recherche, publiés ou non, émanant des établissements d'enseignement et de recherche français ou étrangers, des laboratoires publics ou privés. 
DR. RONAN GARLANTEZEC (Orcid ID : 0000-0001-7420-6341)

Article type : Letter to Editor

Phenoxyethanol, reproduction, and development: additional studies are needed

Keywords : phenoxyethanol, cosmetics, preservative agent, reproduction, development

Number of word : 593

Number of Table : 0

Number of figure : 0

Ronan Garlantézec ${ }^{1}$, Charline Warembourg ${ }^{2}$, Remi Beranger ${ }^{1}$, Cécile Chevrier $^{3}$

${ }^{1} \mathrm{CHU}$ de Rennes, Univ Rennes, Inserm, EHESP, Irset (Institut de recherche en santé, environnement et travail) - UMR_S 1085, F-35000 Rennes, France

${ }^{2}$ ISGlobal, Center for Research in Environmental Epidemiology, Barcelona Spain

3 Univ Rennes, Inserm, EHESP, Irset (Institut de recherche en santé, environnement et travail) UMR_S 1085, F-35000 Rennes, France

\section{Corresponding author}

Ronan Garlantézec.

Irset - Inserm UMR 1085

9 avenue du Prof. Léon Bernard

35000 RENNES

France 
Email: ronan.garlantezec@chu-rennes.fr

Phone : +33 (0) 299289300

\section{Funding : None}

Conflict of interest : The authors declare themselves to have no competing financial interests.

We read with attention the article of Dreno et al. [1] entitled "Safety review of phenoxyethanol when used as a preservative in cosmetics", published in the November 2019 supplemental issue funded by Cosmetique Active International. We would like to respond to their comments on the epidemiological studies we conducted investigating the possible role of phenoxyethanol exposure on reproduction and development.

Epidemiological studies, especially longitudinal cohort studies, provide a posteriori risk assessment in a real-life context to complement European chemical regulations, especially when data are insufficient. The PELAGIE mother-child cohort cited by Dreno et al. fulfils this purpose. This cohort enrolled 3,421 pregnant women before 19 weeks of gestation between 2002 and 2006 in Brittany (France). Questionnaires and biological samples, collected at various times during pregnancy and childhood, allowed assessment of exposure to various contaminants and determination of other risk factors. First, phenoxyacetic acid (PhAA), a metabolite of phenoxyethanol measured in the prenatal urine samples, was detectable in $93 \%$ of the cohort population ( $L O D=0.05 \mathrm{mg} / \mathrm{L}$ ), with a median value of $0.48 \mathrm{mg} / \mathrm{L}$ [2]. Then, higher maternal urinary levels of PhAA measured at inclusion were shown to be associated with (1) a longer time to pregnancy (TTP) [2], (2) variations in steroid levels at birth, including lower levels of hormones involved in the delta-5 pathway among boys [3], and (3) lower performance in Verbal Comprehension at age six using the Weschler Intelligence Scale for Children [4]. Conversely, we observed no association between prenatal PhAA urine levels and (1) major congenital malformations [5] or (2) male genital anomalies using a case-control study design nested in the cohort [6].

Dreno et al. reported most of these results but, inappropriately for a review, mentioned only limitations already extensively discussed by the PELAGIE investigators and only considered them for studies that showed statistically-significant associations. For example, assessment of 
exposure with a single urinary spot for non-persistent compounds is well known to be insufficient to capture intra-individual variability; however, it partially reflects regular, chronic exposure, such as that from using cosmetics. Accordingly, a correlation between PhAA levels in a single urinary spot and a declaration of using cosmetics at work [5] or home [7] has already been reported. Dreno et al. also indiscriminately dismiss the methodology used in our analyses. Contrary to their claim, TTP measurement has been validated and is widely used to study couple fecundity in observational studies [8]. In addition, they argue that this study on TTP and phenoxyethanol "is the only study that showed such results", failing to add that it is the only published study to have investigated this issue, which would relativize their statement. Finally, chance findings and uncontrolled confounding factors are systematic and common - but not always justified - elements that produce doubts in observational studies, but they are also common in toxicological studies, although this is not acknowledged by Dreno et al. Further support of the potential scope of our findings includes the specificity of the associations we found with PhAA relative to other glycol ether metabolites and their concordance with animal data, when available, which suggest, for example, an impact on ovarian function [9].

The conclusion of Dreno et al. that phenoxyethanol can be considered safe when used as a preservative, according to existing toxicological data, is inappropriate and neglects all observational studies. There are indications of potential toxicity and it is important, as acknowledged by the French National Agency for Medicines and Health Products [10], to pursue research on this substance, including toxicological studies (e.g. its endocrine-disrupting potential has only been studied for estrogenic activity [11]) and new epidemiological observations.

[1] Dréno B, Zuberbier T, Gelmetti C, Gontijo G, Marinovich M. Safety review of phenoxyethanol when used as a preservative in cosmetics. J Eur Acad Dermatol Venereol. 2019 ;33 Suppl 7 ; 15-24. .

[2] Garlantezec R, Warembourg C, Monfort C, Labat L, Pulkkinen J, Bonvallot N, et al. Urinary Glycol Ether Metabolites in Women and Time to Pregnancy: The PELAGIE Cohort. Environmental health perspectives. 2013;121; 1167-1173. 
[3] Warembourg C, Binter AC, Giton F, Fiet J, Labat L, Monfort C, et al. Prenatal exposure to glycol ethers and sex steroid hormones at birth. Environ Int. 2018;113; 66-73.

[4] Beranger R, Garlantezec R, Le Maner-Idrissi G, Lacroix A, Rouget F, Trowbridge J, et al. Prenatal Exposure to Glycol Ethers and Neurocognitive Abilities in 6-Year-Old Children: The PELAGIE Cohort Study. Environ Health Perspect. 2017;125; 684-690.

[5] Cordier S, Garlantézec R, Labat L, Rouget F, Monfort C, Bonvallot N, et al. Exposure during pregnancy to glycol ethers and chlorinated solvents and the risk of congenital malformations. Epidemiology (Cambridge, Mass). 2012;23; 806-812.

[6] Warembourg C, Botton J, Lelong N, Rouget F, Khoshnood B, Le Gleau F, et al. Prenatal exposure to glycol ethers and cryptorchidism and hypospadias: a nested case-control study. Occup Environ Med. 2018;75; 59-65.

[7] Nisse CL, Thomas T, Leroyer J. Characterization of exposure to glycol ethers of a sample of the general population of northern France. Toxicol Analytique et Clinique. 2017;29; 418 - 440.

[8] Joffe M, Key J, Best N, Keiding N, Scheike T, Jensen TK. Studying time to pregnancy by use of a retrospective design. Am J Epidemiol. 2005;162; 115-124.

[9] Multigner L, Catala M, Cordier S, Delaforge M, Fenaux P, Garnier R, et al. The INSERM expert review on glycol ethers: findings and recommendations. Toxicol Lett. 2005;156; 29-37.

[10] ANSM. Comité scientifique spécialisé temporaire. Utilisation du phénoxyéthanol dans les produits cosmétiques 2017. Available at https://www.ansm.sante.fr/var/ansm_site/storage/original/application/e0696c469e0d32005731 ecc04c015214.pdf [last accessed 20/11/2019]

[11] Morohoshi K, Yamamoto H, Kamata R, Shiraishi F, Koda T, Morita M. Estrogenic activity of 37 components of commercial sunscreen lotions evaluated by in vitro assays. Toxicol In Vitro. 2005;19; 457-469. 